\title{
Representation of the Impulsive Temperament in Arts, Literature and Science: From the Middle Ages to the Present
}

\author{
Hendrik Marten Koolma ${ }^{1,}$, , Adila van Dreven ${ }^{2}$ \\ ${ }^{1}$ Department of Public Administration and Social Sciences, Faculty of Social Sciences, Vrije University Amsterdam, Amsterdam, the \\ Netherlands \\ ${ }^{2}$ Alumna of the Department of Human Geography and Spatial Planning, Faculty of Geosciences, Utrecht University, Utrecht, the Netherlands
}

Email address:

h.m.koolma@vu.nl (H. M. Koolma), adilavandreven4@gmail.com (A. van Dreven)

${ }^{*}$ Corresponding author

\section{To cite this article:}

Hendrik Marten Koolma, Adila van Dreven. Representation of the Impulsive Temperament in Arts, Literature and Science: From the Middle Ages to the Present. International Journal of Literature and Arts. Vol. 9, No. 2, 2021, pp. 79-93. doi: 10.11648/j.ijla.20210902.15

Received: March 19, 2021; Accepted: April 9, 2021; Published: April 16, 2021

\begin{abstract}
In this contribution, we intend to review the way in which personality is typified and represented through the centuries in arts, literature, and science. The scope ranges from primitive paintings in the Middle Ages to reports made by means of questionnaires developed by psychological scientists. During the centuries, the leadership temperament has been shifted from the choleric toward the sanguine temperament. The resulting extraverted character and personality have come into the picture and thus, have raised new problems for explication and interpretation. Further, there is a remarkable similarity between the medieval representation of the four temperaments and trait dimensions in recent neurophysiological and biological research. In contrast, the questionnaires show a stepwise development of increasing negligence of elements of the impulsive personality, or, in medieval terms, the choleric temperament. This tendency in mainstream personality test design is criticized by some researchers. In this article, we suggest that this development is caused by a romantic hankering after an ideal of leadership. There is a symbolic layer in the verbal reasoning through which the steps to impulsivity-free personality representations have been made. Surprisingly, this tendency is absent in a personality representation derived from adjectives in the English language. Finally, we raise the question of whether it is sensible to shut our eyes for the presence of the choleric temperament in our contemporary society.
\end{abstract}

Keywords: Leadership Romanticism, Heroism, Temperaments in Arts, Personality Research, Individual Differences, Impulsivity, Extraversion

\section{Introduction}

In this contribution, we intend to review the way in which personality has been typified and represented through the centuries in arts, literature, and science. Personality and health care have been based on the idea that four temperaments constitute people's personality and disposition. The scope ranges from primitive wood engravings in the Middle Ages to reports resulting from questionnaires developed by psychological scientists. In this article, the focus is on the choleric or impulsive temperament, because of its association with leader-like behavior.

In recent accounts on human temperament [1,2], a short way is taken from the medical science of the ancient Greek to the research on biological foundation of personality by Hans
Eysenck and colleagues. However, it is interesting to shed light on the evolution of the temperament doctrine in the intermediate millennia. The four temperaments reappeared in Western Europe in the second part of the Middle Ages. Explication of differences in the exhibition of personality was done by pieces of arts. In the representation of heroes, symbolic signs supported the way in which they should be appraised by the observers. The temperament doctrine lost its substantiation by progress in medical science. In addition, the cultural revolution of the Age of Enlightenment and the counter movement of Romanticism radically changed the conception of personality. The change consisted of a transformation from temperament to character and of a revision of the relation between man and nature.

In this article, we attempt to interpret personality 
representations in recent psychological research from the evolution of the temperaments doctrine and the way in which the choleric temperament of heroes has been represented by artists.

This article is part of a research program on the creative and destructive sides of leadership in organizations and institutional fields. In the course of this program, irregularities were encountered in the temperament research that gave rise to questions and made us curious whether the history of the four temperament would give clues to answers.

\section{The Four Temperaments Represented in the Middle Ages}

\subsection{The Ancient Greek Origin of the Temperaments Theory}

Although the focus in this article is on personality representations from the Middle Ages, some attention has to be paid to the origin of the four temperaments concept. Commonly, authors refer to the advancements in the medical sciences made in ancient Greece [1, 2]. The best-known medical scientist is Hippocrates [3], but in his track Galen, also known as Galenus, made a further contribution to the four temperaments theory [4]. In an alternative term, the humoral doctrine, a referral is made to the physiological basis of the approach. Humor origins from Latin, where its meaning is liquid or fluid [5]. In the doctrine, four fluds of the body determine the temperament and features of the person: blood (sanguine), phlegm, yellow bile (choler) and black bile (melanch-choler). Variant mixtures determined a person's physical and mental qualities, and his or her disposition [1, 2, 5]. A survey of the types and features is provided in table 1.

Table 1. Four temperaments, the behavioral expressions and the assumed physiological base.

\begin{tabular}{ll}
\hline Temperament & Features and anatomical source \\
\hline \multirow{3}{*}{ Melancholic } & $\begin{array}{l}\text { The melancholic type has a tendency to sadness and depression, and relates with a pessimistic view to the world [1]. Attributes of this } \\
\text { character are: despondent, quiet, analytical, serious. } \\
\text { The fluid in abundance is said to be black bile, although in nowadays' autonomy the source of the fluid is not clear [1]. Originally, the } \\
\text { spleen was indicated as the excreting organ [3]. }\end{array}$ \\
The phlegmatic type displays an absence of impulse in its behaviour, and is associated with slowness, laziness, and dullness [1]. More \\
Penign adjectives of this character are: calm, thoughtful, patient, peaceful [3]. \\
This temperament is caused by an abundance of phlegm of mucus. Cold hands form a psychical indicator [1]. \\
The sanguine type expresses optimism, is easy in company, and tends to be reconciled with his or her living conditions [1]. Kalachanis \\
and Michailidis attribute to these adjectives: courageous, hopeful, playful, and care-free [3]. \\
Thing temperament is attributed to an abundance of blood supply, a healthy complexion, featuring rosy cheeks [1]. \\
The choleric type is characterized by an impulsive temper, often tending to expressions of aggression [1]. Kalachanis and Michailidis add \\
the following adjectives: ambitious, leader-like, restless, easily angered [3]. \\
Choleric & $\begin{array}{l}\text { Abundance of yellow bile, excreted by the gall bladder, contributes to this temperament, and displays itself in physic features like a } \\
\text { yellow complexion and tense muscles [1]. }\end{array}$ \\
\hline
\end{tabular}

In contemporary psychological representations, the impulsive trait is mixed with sociability and termed extraversion $[6,7]$. Hence, the mixture of the choleric and sanguine temperament is taken into consideration too. It is important to note that in ancient writings the physiological (or biological) and the behavioral (or psychometric) explications of the temperaments coincided. In other terms, the genotypical and phenotypical aspects of temperaments [8] did not diverge.

The relationship with personal qualities reflected Aristotle's midway thinking [9]. The basic reasoning is that the fluids or humors regulate both health and character around an equilibrium or, in Greek, homeostasis. People needed to have an optimal proportion of each fluid, not too little and not too much. If one possessed a fluid in excess, one exhibited an extreme personality according to the pictorial typology. Furthermore, Aristotle called a harmonious mixture of humors eucrasia, whereas dyscrasia was the term for a unbalanced mixture [3, 2].

In the Middle Ages, scholars and practitioners fell back on the Greek tradition. The historical path is interesting. Whereas in Western Europe the scientific development of medicine and personality theory was suspended (The Dark Age, 500-1000), the Arab world took the lead [9]. A proliferation of the Arabs' advancements both in culture and science started from the Iberian Peninsula. The Greek tradition of the humoral doctrine in medicine and personality explication was handed over as textbook knowledge and medical practice to medieval society. In the late Middle Ages, particularly the personality assumptions of the doctrine were disseminated by representations in arts.

\subsection{Medieval Representation of the Four Temperaments}

An early 16th century representation of the four temperaments from the 'Shepheards Calendar' is in wood print.

From the left to the right, one observes a choleric, a sanguine, a phlegmatic, and a melancholic person respectively accompanied by a lion, an ape, a ram, and a pig. The drawn sword in the hand of the choleric man is a repeatedly added symbol through the Middle Ages, just like the accompanying lion.

The text in figure 2 says: 'The choleric temperament in front of the fire. A lean man, yellow tinted with a fiery expression, almost naked with a drawn sword in his right hand, standing with potency and the willingness to fight.' The title of the illustration draws the attention to the mirroring shield by which the glowing fire inside the choleric man was reflected. By absence of a noble heritage, the colerico could only bring his fiery nature into the battle. 


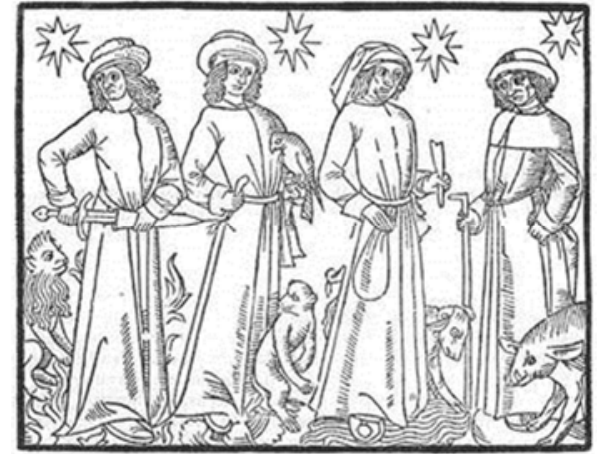

Figure 1. Engraving from the Shepheards Calendar, artist unknown.

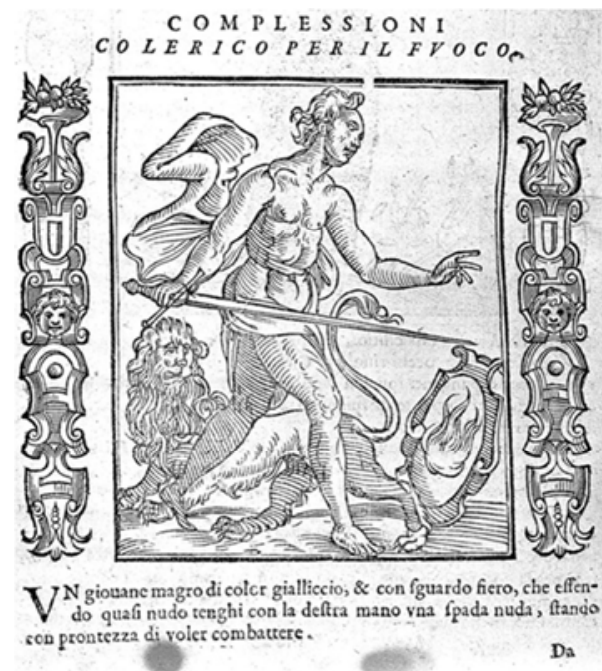

Figure 2. An Italian drawing of the choleric temperament [10].

The next early wood engraving was accompanied by an explication in Latin. In Western Europe, Latin was the universal language among scholars and other members of the educated elite. Non-educated people were depending on them for the translation into their vernacular.

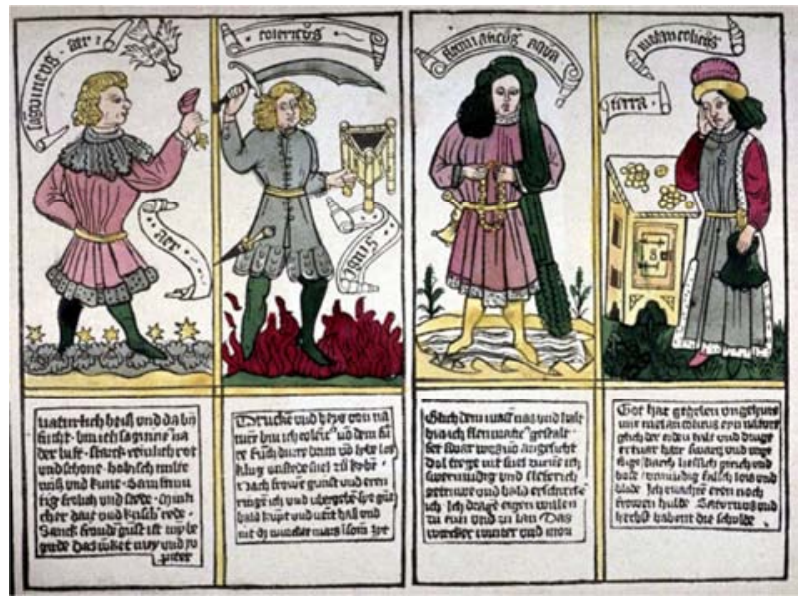

Figure 3. Wood engraving of four temperaments, picture used for a lecture by Rudolf Steiner, March 9th 1909 at Berlin.

Similarly to the Shepheards Calendar (figure 1), the people are portrayed on four differing bases representing the four elements. In ancient times, Hippocrates had proposed a foundation of the temperaments on the four elements of the universe in the following combination $[3,21]$ :

Table 2. The relations between temperaments and universal elements.

\begin{tabular}{lllll}
\hline Temperament & Sanguine & Choleric & Phlegmatic & Melancholic \\
\hline Element & Aer (air) & Pyrus (fire) & Aqua (water) & Terra (earth) \\
\hline
\end{tabular}

In a master piece of medieval Dutch painting, the Brothers of Limburg presented an integration of the four temperaments into the body of contemporary science. Their work has become famous for the use of splendidly saturated blue and gold pigments. The Brothers of Limburg explicated a connection between the four temperaments doctrine and astrology. The next illustration is a part of the religious Book of Hours (Les très belles heures), commissioned by the Duke of Berry, brother of Philips the Bold, king of France. The Book of Hours was completed by others, just after the deaths of the brothers in 1416. As the Duke of Berry suffered from an innate poor health, he thought it important to display markers of the medical sciences of those days [11].

The text fragments in the corners explicate the relation between the twelve astrological signs and the four temperaments which determine the character of the human being. The humors are connected to the four celestial directions and the two gender types as well [11]. The twelve astrological signs are in their turn connected to the four temperaments.

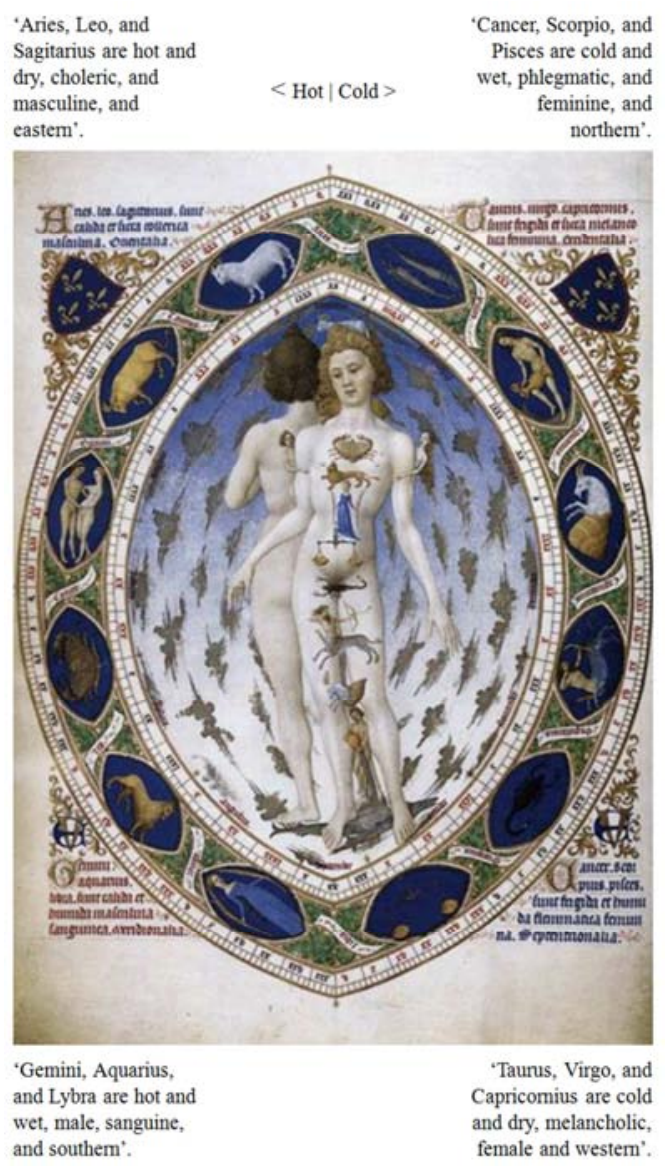

Figure 4. From Book of Hours, Museum of Condé, Chantilly, France. 
This representation of the four temperaments displays the humors no longer in a random sequence or by a set of separate paintings, but in a deliberate order. When the scheme was redesigned into a crossing of hot-cold and wet-dry, the choleric temperament would be the opposite of the phlegmatic, and in turn, the sanguine the contrary of the melancholic. However, in the presentation by the Brothers of Limburg, the division between masculine and feminine temperaments was the central ordering criterion.

\subsection{The Frisian Hero and Pirate Grutte Pier}

Pier Gerlofs Donia, alias Grutte Pier (Big Pete) was a real person and is regarded as a tragic hero in the Frisian and Dutch history. He lived in Frisia from approximately 1480 to 1520 . At that time, the county was without a central authority, and surrounded by the county of Holland, the duchy of Gelre, and the duchy of Saxony, whose leaders competed for its annexation [12]. The failed state situation provided a freeway for gangs of robbers, murdering militias, and plundering troops of mercenaries. In 1516, the village of Kimswerd was raided and reduced to ashes. Pier's farm was lost too, whereby his wife probably lost her dignity and life [13]. It is reported that Pier and his children survived the raid [12]. He is said to have sworn revenge against whom he held responsible for the raid. He gathered a gang of men for an offensive militia and raided the Frisian town of Franeker. He chose the side of the enemy of his enemy, the duke of Gelre, although this nobleman had a double agenda concerning the autonomy of Frisia. Pier continued his battle against the county of Holland by a guerrilla naval force on the Zuiderzee (inland sea of the Netherlands). Landing in the northern part of Holland, he raided and destroyed farms, villages, and the town of Medemblik [14, 12]. He continued his battle even after an armistice was agreed on by the stadtholder of Holland (the later emperor Charles V) and the duke of Gelre. Most of his fellow Frisian leaders defected to the stadtholder of Holland. In the four years till his anonymous death in 1520, he was the terror of the citizens and merchants of Holland. From his death till today, his histography has been the subject of an ongoing controversy between Frisian and non-Frisian Dutchmen: Pier is either a people's hero and freedom fighter or an ordinary pirate and war criminal $[12,13]$.

Pier's physique contributed to an image of a man with an aggressive disposition, 'a hideous cruel man'. The most credible sources of information were the contemporary chroniclers Peter and Worp of Thabor. Peter of Thabor depicted Pier as 'a big, black man, broad-shouldered, gruesome in appearance' [12: 40]. In later historical accounts, Pier became the subject of mystification in two opposing nationalistic discourses. Pier's terrifying features and actions made him even the bogeyman for children in Holland, the alleged origin of Black Pete [15]. Pier's actions, such as drowning people from raided ships, taking hostages, and the murdering of civilians after the capture of towns, villages, and farms were indeed merciless and cruel. However, his actions were not uncommon in the warfare of those days [14, 12]. But in his case, the exhibited cruelty was easily attributed to his disposition. On the other hand, his desperate need for revenge and impulsive, fearless actions made him the ultimate naval guerilla commander. Kalma has suggested that Pier received historical reviews that were different from the nobleman involved in the same battles [14]. He was only noticed after some victories. Here, it is assumed that his peasant descent made him more suited for the framing as a savage man compelled by impulse.

\subsection{Lumey, Admiral of the Dutch Freedom Fighters}

50 years later the Willem of the Marck, Free Lord of Lumey, operated in a strikingly similar way. He swore revenge for the execution of his fellows in the pursuit of Dutch independence, the dukes of Egmond and Hoorne. The execution was commissioned by the Spanish stadtholder, Alva. Lumey became a successful admiral of a naval guerilla fleet. His capture of the town of Brielle in 1572 had been conducted in a rather unpremeditated way and was, in hindsight, disapproved of by Willem of Orange, the later hero of the Dutch war of independence. Out of anger for not receiving the respect of Willem of Orange, he impulsively decided to execute 17 clergymen whom he had taken into hostage, the martyrs of Gorcum [16]. Just like Grutte Pier, he lacked the political cunning of his fellow fighters in command. After he had been arrested and deprived from his title of admiral of the Geuzen, he disappeared disillusioned from the stage. In later controversies between Dutch reformists and Roman Catholics, he was discredited for his cruelty, although his actions were common in the warfare of those days $[17,16]$.

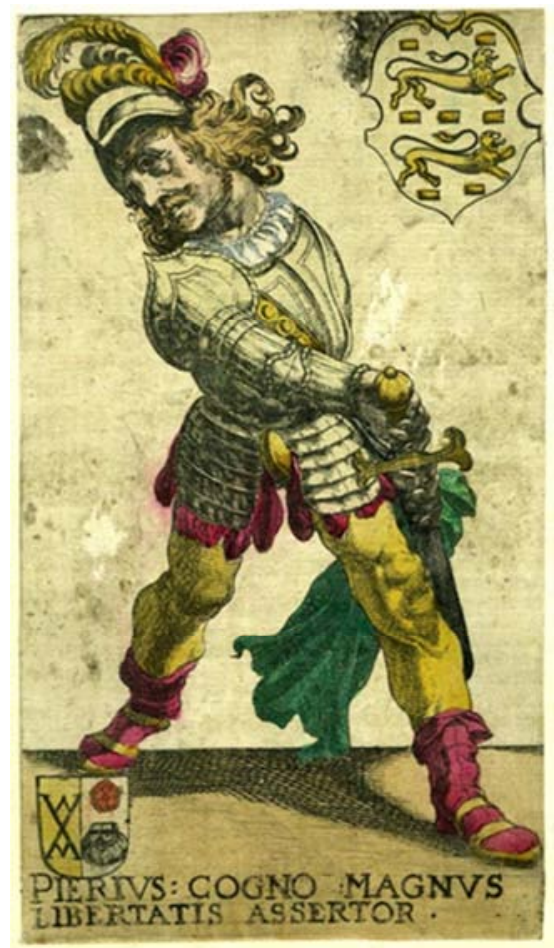

Figure 5. Drawing of Grutte Pier from Winsemius's Chronicle, issued in 1622, drawing in possession of the Frisian Museum at Leeuwarden, the Netherlands. 


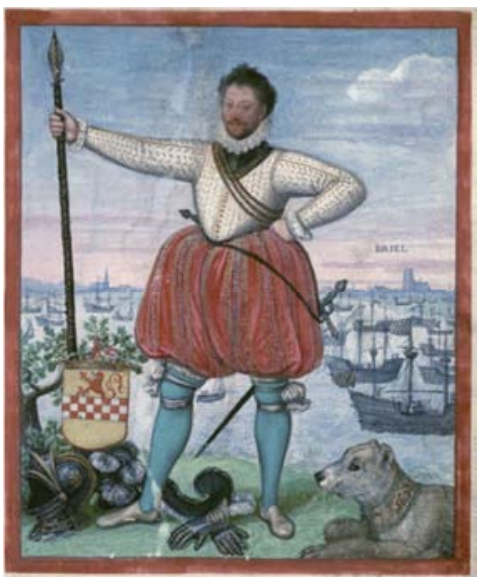

Figure 6. Willem II van der Marck, Free Lord of Lumey, portrayed after the capture the town of Brielle in 1572, author unknown, in possession of the Dutch National Archive, the Netherlands.

In contrast to Lumey, Grutte Pier is portrayed clearly as an example of the choleric man. He is displayed with the former crest of the county of Frisia though in contrast to the original version of the crest, the lions are looking to the right. It is unknown, whether this was an error, or that the mirroring was done on purpose. The drawing was made a 100 years after his death, whereas the representation was based on written descriptions of contemporary historians. The drawing by Lumey is probably 50 years older, rendering him in a static pose according to the late-medieval style of painting. Part of his armor has been discarded. His family crest is presented as a sign of his distinction and his noble descent.

\section{Turning Point: The Age of Enlightenment and the Counter Movement of Romanticism}

\subsection{Temperaments Doctrine in the Age of Enlightenment}

The popularity of the temperaments decreased at the end of the Middle Ages. Progress in medicine, and particularly the anatomy, raised doubt about the causal model underlying the four temperaments [18]. Hence, the genotypic explanation became obsolete. The phenotypic explication of temperament was affected by the cultural revolution of the Enlightenment. In this regard, two authors have to be mentioned, namely Jean-Jacques Rousseau and Immanuel Kant. They initiated a radical shift in personality approach, from nature to nurture and from temperament to character. Rousseau paved the way for developmental psychologists like Piaget and, more recently Veroff [19]. Kant's account forestalled the work of Wundt, Eysenck, and Gray [2, 6-9].

\subsection{A Revolutionary Novel by Jean-Jacques Rousseau}

Jean-Jacques Rousseau's most important publication in this regard is his treatise Emile, or on Education [20]. Rousseau chose a dramatic novel form in which narrators converse with the child Emile and with one another. Although obsessed with the anticipation of being misunderstood by readers and criticasters, Rousseau's narration is of a confusing complexity [21]. In spite of its rather inaccessible narration, his treatise has become popular and influential through the centuries. As Rousseau has had a vocational education as an engraver, he commissioned very deliberately engravers to craft illustrations for the editions of Emile [22].

There are references to Greek mythical figures, of which Achilles's nurture is set as an example for Emile's education. The centaur Chiron, notably half animal and half human, is not fiercely and menacingly standing but bowing. He is taking care of a part of Achilles's education. His armor is discarded and lying on the ground. Symbolically, Rousseau draws a departure from the state of a natural human being. Achilles is told not to follow a military career but to compete in a running game with other youths, Its prize, being an apple, is offered by Chiron [22: 13]. The hare dangling from Emile's right hand looks like a prey from the hunt, but more probably, refers to the tale of a running race between a slow steadily crawling tortoise and an explosively running hare. In a state of overconfidence, the hare took a nap halfway through and lost the battle.

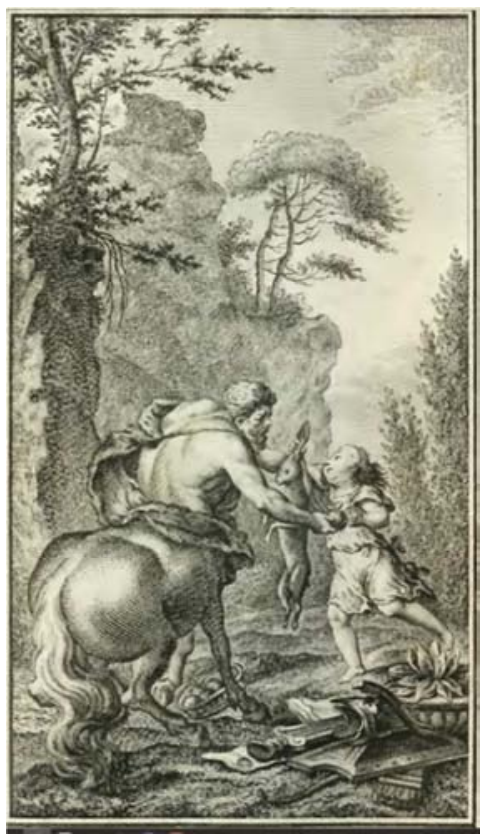

Figure 7. Chiron \& Achilles, Chapter II prior to p. 69.

The next text fragment is more directly an objection made by Rousseau to the impulsivity of natural man. It is a lesson conveyed to man to free himself from the possessive force of temperament and associated passions. Rousseau suggests that in the development of the child, it ought to learn to control of his anger, hot temper, and other hefty passions in general.

Comment concevrois-je qu'un enfant ainfi dominú par la colere, \& dévoré des paffions les plus irafcibles, puifte jamais être heureux? Heurcux, lui ! c'eft un Defpote; c'eft ù la fois le plus vil des efclaves \& la plus miférable dés crćatures. J'ai va des en-

Figure 8. Text fragment on passion from Emile [20: 88].

'How am I convinced that a child so dominated by anger, \& 
devoured by the most hot-tempered passions, will never be happy? Happiness, he is a despot. Once, it is the most prominent of slaves and the most inferable of creatures.' [20: 88]

\subsection{Immanuel Kant's Pioneering Thoughts on Personality}

In his treatise titled Anthropology from a Pragmatic Point of View (1789/2000), Immanuel Kant distinguished the ancient typology of temperament from character. He described temperament as "what nature makes of the human being" ( $p$. 192), whereas character refers to "what the person makes of himself" (p. 192) through willful thought and action and the application of virtue [2: 5]. According to Rothbart, Kant's virtue conception was related to moral ideals. Kant proposed a dimensional approach of personality in which a continuum from inactivity to activity is crossing a dimension of variable levels of emotionality [2: 6]. His mathematically conceived dimensions replaced the representation by pictorial personality types. Kant was very important among authors of the Enlightenment who sought their way by means of the logic of scientific rationality, contrary to traditional beliefs in authority and people's common preference for ignorance and superstition. This Age of Reason was soon followed by the cultural counter movement of Romanticism [23].

\subsection{Romanticist Reconception of Personality and Nature}

A key to the Romanticist treatment of personality is provided by a recent movement in leadership research. In 1985, Meindl and colleagues published a paper on 'The Romance of Leadership' [24]. Their main argument says that in situations of uncertainty and complexity, followers tend to attribute exaggerated discretionary power and competence to their leader in the hope for positive outcome. Conversely, when confronted with negative outcome followers will hold their leaders accountable to an extent that overestimates the leader's control over outcome and his or her contribution to failure. Briefly, the leaders are romanticized, either one-sidedly positively or one-sidedly negatively, while their alleged successes respectively failures are beyond inquiry and criticism. This irrational strategy of uncertainty reduction makes followers prefer leaders who believe in their own infallibility and, as a consequence, displaying evident narcissistic personality indicators [25], or acting without behavioral inhibition [26]. Collinson and colleagues argue that the romanticist mechanism not only affects the appraisal of individual leaders by followers, but also biases scientific leadership approaches [23: 1628].

Put on track by the term Romance, Collinson and colleagues have extended their research scope to the historical and social-cultural discourses on Romanticism [23: 1626]. According to Ferber [27, 28], 'Romanticism is typically understood as an artistic, intellectual, literary and even social-political movement that sought to recapture a sense of proportion with regard to humanity's relationship to nature.' [23: 1628] The social-political aspect is that an approach inspired by romanticist thought emerged during the 18th and the 19th century. The approach appeared in the form of projects on nation building and of religious revival. For instance, in the centuries after his death, Grutte Pier's histography was in romanticist regard affected by the project of reestablishing Frisian identity, while his simple rural descent served the opposition of Frisian opinion leaders in their resistance against the dominance of the Dutch urban elite [12]. Similar identity reinforcing projects were set up in Western Europe in reaction to the modernization and industrialization. [30] According to Löwy and Sayre, 'romanticism emphasized that which was being lost: human subjectivity, emotions and imagination, human embeddedness in nature and the romantic idyll of rural communities. In this sense, romanticism was utopian, fundamentally shaped by idealism, nostalgia and a sense of loss.' [30]

Romanticism objects to the Enlightenment's assets of rationality, analytical observation, and control. In contrast, Romanticists believe that people need to follow their emotions, intuition, and imagination to achieve their true self. As nature is an idealized concept [31], being connected to nature will be a lofty affaire as well. Notably, it is not the nature of one's biological disposition that is sought after. Just like the Enlightenment, Romanticism detached man from his or her temperaments and his or her ambiguous mixture of virtues and vices just as well. However, the search for lost memories brought romanticist artists to a preference for the melancholic temperament in the characters of their novels, the mood of their poems, and the portrayal of people. [32]

For instance, a group of French writers received the epithet poètes maudits, namely, Charles Baudelaire, Paul Verlaine, and Arthur Rimbaud. Spleen was the word which reflected the soul of their works and their way of life. In ancient medicine, the spleen was the human organ that was indicated as the source of the melancholic temperament. [3: 2] Hence, during Romanticism, profound emotionality became more often associated with melancholic feelings of sorrow and sadness than with other temperaments.

\subsection{Four Temperaments as a Scheme for a Symphony}

A direct reference to the four temperaments was made by Carl Nielsen, a Late-Romantic composer. His second symphony bears the same name and has been published in 1902. Carl Nielsen was born in 1865 as a son of a farm worker and village musician [33: 463]. He was educated by Gade in the tradition of the German Romanticism of Brahms. In the second half of the 19th century, a Danish style was developed. Nielsen is seen as the most famous Danish composer of his time, although his fame abroad cannot compete with the Norwegian an Finnish composers Grieg and Sibelius. These composers were more engaged in the development of a nationalist identity-based music practice than Nielsen.

Like many other artists, Nielsen visited the countryside in search of ideas and inspiration. During a visit of a village on the Danish isle Zealand, he was struck by a set of primitive medieval paintings portraying the four temperaments. In particular, the painting of the choleric man drew his attention. Nielsen recollected the picture as portraying a man on 
horseback with a long sword in his hand, with which he slashed wildly at the empty air. "His eyes were nearly rolling out of his head, his hair flew madly round his face; it was so full of fury and devilish hate that involuntarily I burst out into a laughter." [34]

In in its elaboration, Nielsen's work is more a classical symphony than a piece of program music. He used the four temperaments for assigning contrasting characteristics to the four movements of the work. The creative procedure is similar to the use of the four temperaments as cast template in films and novels. The score has the following partitioning:

First movement Allegro colerico

Second movement Allegro comodo e flemmatico

Third movement Andante malincolico

Fourth movement Allegro sanguineo

In other symphonies the tempo indication of the first movement would have been allegro con fuoco. However, the piece as a whole breathes the ironic atmosphere and light touch of Haydn's symphonies, just like it is found in the symphonies of his Russian contemporary Prokofiev.

\subsection{A Hero in a Remake of a Hungarian Folk Tale}

The Hungarian post-romantic composer Zoltán Kodály took a hero from traditional folk tales, János Háry as main character for a musical play [33: 543], and an adaptation to an orchestral suite (1926). The compositions result from an extensive project having taken years that Kodály had carried out in close cooperation with his friend and fellow composer Béla Bartók. The project entailed the recording and documentation of traditional music in Hungary and neighboring countries. Both composers were dedicated promoters of a Hungarian style of composition and performance [35]. The idea of taking an ancient folk hero as the basis for a musical play and orchestral work had been done before by Richard Strauss in his symphonic poem Till Eulenspiegel lustige Streiche (1895). However, Strauss did not have in mind a revival of traditions when musically portraying this hero from Flemish-German folk tales.

János Háry is just like Till Eulenspiegel and the Baron of Münchhausen an example of a boaster. According to tradition, János Háry lived in a village in the rural region of Great Agony. [36] The plot of the musical play and suite is dated in the period of the defeat of the French emperor Napoléon. After his military service, János Háry returns to the village where he lived before, and he starts telling his fellow villagers about how he personally defeated Napoléon. It was not only the battle that he had won in Milan. The daughter of Napoléon, Marie-Louise fell in love with him. Instead of becoming the next emperor of the French empire, he returned to rejoin his girlfriend in the village.

This entertaining folk hero is shown on record covers in backdated imitation styles. The next illustration imitates the art of primitive painting, however the pistolet is clearly an anachronism.

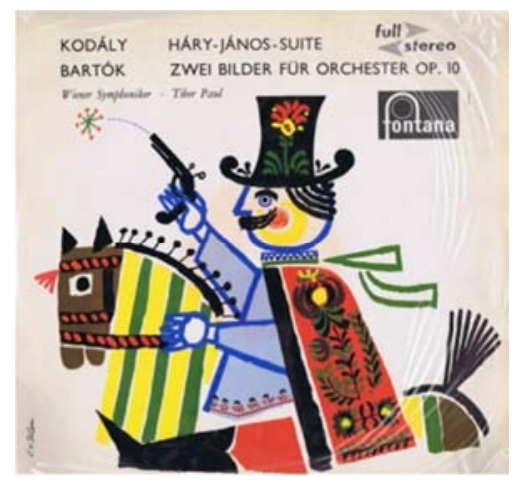

Figure 9. János Háry on a Fontana record cover.

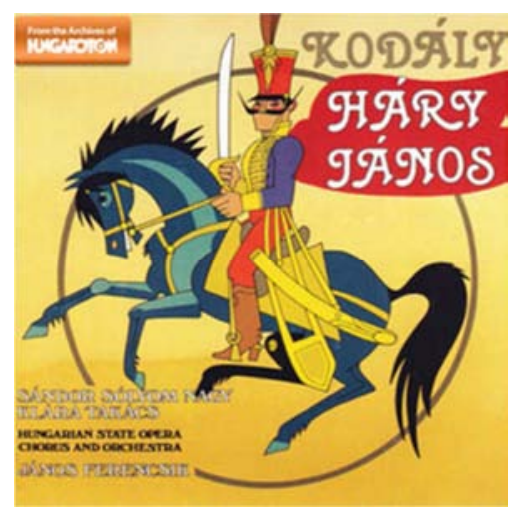

Figure 10. János Háry on a Hungaroton record cover.

The second illustration resembles representations of the military made by painters in the Napoleonic era. In both illustrations János Háry is portrayed with the features and pose of a choleric man: aggressively riding on an armored horse, fiercely showing a drawn weapon. However, the rosy cheeks of 9 and 10 are an obvious indicators of a sanguine temperament [1:3]. This mixture of choleric and sanguine temperaments is nowadays termed extraversion [6]. The showy moustache suggests a flamboyant personality, a feature of extraverted behavior too [37]. This combination of the impulsive and sociable personality traits is in accordance with the narration.

János Háry, the musical play, equires a historical political interpretation. First, Háry's adventures are dated in a period of the decline of the Habsburg Empire at the heart of which were Hungary and Austria. Napoleon conquered this empire, but lost his wars in Russia and, finally, at Waterloo in a battle against the Duke of Wellington. An Austrian-Hungarian defeat reoccurred at the end of World War I, when this double nation surrendered together with Germany. In Hungary, the Treaty of Versailles was experienced as a humiliation, just like the temporary occupation and control by the French army, one of the troops of the winning alliance [36]. The musical play appealed clearly to feelings of loss, which were countered by fantasies of heroism and of victory, both in combat and love. Defeat was reframed into victory by means of imagination and expressed by narratives. The play was fueled by reviving nationalism and hatred against the French. Besides the French, also several minorities in Hungary had to pay for the sentiments about the lost national pride. Especially, Czechs 
and Jews were repeatedly targeted by Háry's verbal ridicule [36: 116].

It is important to emphasize that Kodály did not agree with the sentiments in the play: 'He himself noted that János Háry's world view is "Hungary-centric". "I never claimed," said Kodály, "that it is good because of this. On the contrary: many of our old sins, the political errors of Hungarian history, are ingrained therein. The task of art is not to teach, judge, or convince; it needs only to represent."[36: 114] After the Holocaust, Kodály, withdrew a part of the score called The Jewish Family [64]. Through the years, János Háry, as brought to life in the play has remained very popular among Hungarians. Kodály supposed that Háry represented the spirit of the Hungarians [36: 116].

The appraisal of János Háry as a hero reveals two aspects. First, the combination of choleric and sanguine temperament contributes to popularity among followers, just like the tendency to boast. Second, considering the historical political interpretation, a mainly fictive person who is able to redirect feelings of loss and hatred into feelings of national pride and superiority, expressed by the humiliation of minority groups, is suited to play the role of a people's hero. The one-sided positive and lofty representation of romanticized leadership is replaced by prototypicality [38]: Groups follow leaders who apparently have their bad habits and negative sentiments in common [39],.

\subsection{A Heroine in a Path Breaking Novel}

Tess d'Urbervilles, A Pure Woman Faithfully Presented is an intriguing investigation into the character and emotions of a female hero, created by the Late-Romantic novelist and poet, Thomas Hardy. The novel's first issue was in the form of a serial publication in the Graphic magazine in 1891 [40]. Just the subtitle evoked consternation and fierce criticism of contemporary reviewers. The main argument was that a woman who finally kills her rapist without pity, cannot not possibly be pure [40: 274]. Under the pressure of public indignation, Hardy revised the foreword and the scene of the murder several times until his final version of the novel in 1912 [41, 40: 278]. In recent years, the novel has served as a plot for movies $(1979 ; 1998)$ and a television series (2008).

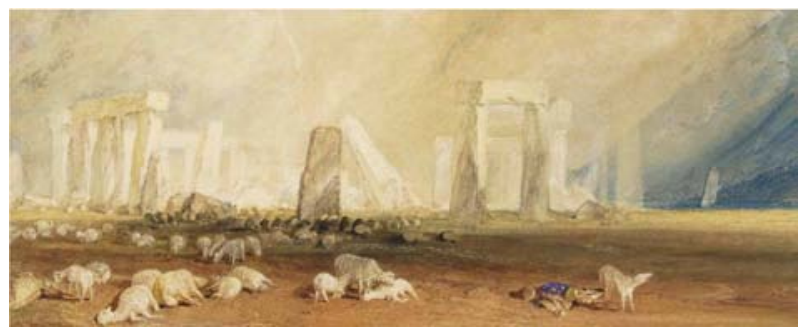

Figure 11. Turner's water color painting of Stonehenge, displaying a shepherd lying dead after being struck by the lightning. Salisbury museum (www.salisburymuseum.org.uk). Cover of a Penguin issue of Tess of d'Urbervilles.

The relatively voluminous novel has a simple plot, obviously inspired by the medieval genre of the ballad [42], and, particularly, the tale of the fallen maiden who takes revenge. Briefly, the plot is as follows [43]: Tess Durbeyfield, the beautiful daughter of a farmer is seduced and raped by the feudalist Alec d'Urbervilles. She becomes pregnant, but she and her family are not compensated for the rape by Alec. A period of hardship and sorrow begins until her baby dies. Tess is free again, and marries Angel, the atheist sun of the reverend Clare. In the wedding night, Tess confesses to Angel that she is not a virgin anymore. Angel leaves her, and emigrates to Brazil. When he returns, he discovers that Tess is giving in to the relentless pressure on her by Alec to resume an liaison with him. She consents finally, but murders him with a dagger at the moment when Alec expects to have sex with her again. She confesses her crime to Clare. Together, they decide to flee. After a night spent sleeping at Stonehenge, the couple is caught. Tess is brought to the gallows. Shortly before her execution, she arranges a marriage between Clare and her younger sister, Liza-Lu.

The novel is full of symbolic imagery that is described as blunt, poignant, bloody, and erotic, although the mirroring between the descriptions of the countryside of Wessex and the emotional development of Tess are of a wonderful beauty and compelling synchronicity [44, 45, 41]. Tess is presented as a natural but ambivalent woman: she is charming, cheerful, and pleasant to be with on the one hand, very frank, rather fearless, impulsive and hot-tempered on the other hand [45: 63-65]. She seems to combine the choleric and the sanguine temperament, and, thus, displays an extraverted personality before the term was coined.

The use of the four temperaments as a template for the role cast is illustrated by the description of the characters and their contrasts at the major plot twists. Angel is averse to action and hot-temper. Rather, he is a man of words and reasoning ceaselessly. He does not challenge his rival and attacker of his beloved Tess, and he does not take up arms when Tess is facing her arrest. Angel has the features of the phlegmatic temperament. Before they separate at the bridal night, Hardy forces the reader to a close observation of a fire [45: 87-88]. This interruption of the action in the plot has a symbolic meaning. We suggest that fire is the underlying element in which Tess differs from Angel. Contrary to Angel, Alec is uninhibited, aggressive, and relentless in his contacts with Tess. The symbolically asserted difference in the relationship between Alec and Tess is blood. Scarlett, notably not

red, blood flows from Alec's cheek when Tess struck his face with a leather glove [45: 87-88]. At the final moment of the separation, a flood of blood signals the discovery of the murder. Alec and Tess share the choleric temperament. At a scene far before the murder, Parker notes: 'Tess's outburst of emotion, as an aspect of her character, is potentially convincing, since her tendency toward violence is prefigured in the novel when she almost knocks Alec from the gig, "her eyes flashing as the latent spirit (of which he was to see more at some day) awoke in her" [40:278]. The flashing eyes are an obvious indication of the choleric temperament. In the scene preceding the murder, Tess's dagger is presented as a naked sword. The scene contains an allusion to Alec's assaulting intrusion into Tess's body, an act that will be reciprocated by 
Tess [45: 77]. Hence, both are symbolically associated with the choleric man and the menace of his weapon. However, unlike Alec, Tess has a sanguine temperament as well, symbolically indicated by blood. Besides, after the rape Tess goes through a phase of sorrow and self-remorse, but the melancholic temperament does not endure, simply because it is not in her nature to be depressed. Finally, the younger sister Liza-Lu is said to have the same virtues as Tess (beauty and warmth), but not her vices. Remarkably, when the novel was published, the bi-polarity of the character of Tess was not accepted, as mentioned afore. According to criticasters, Tess could not be indicated and justified as a pure woman by Thomas Hardy, because of her exhibition of satisfaction with her revenge [40: 277]. It points out that impulsivity and aggression as expressions of the choleric temperament, can arouse positive emotion, in dissonance with negative moral judgments from society.

As Tess is the hero featuring in the center of this romantic novel, the consequence of the romance of her leadership is that she has to show a character that is either positive or negative, but not both within the same person. Because of her appealing sanguine temperament, the choleric temperament became the odd man out in the reception of the novel, partly due to Hardy's call for a not too harsh a moral judgment on his well-beloved creation, Tess [41]. By arguing that her final actions had not emerged from her normal character [40: 274], Hardy contributed to the idea that this internal incompatibility of humors in Tess was not innate, but abnormal and compelled by her tragic fate [40: 277]. However, his aim was to ground Tess's character on the laws of nature in contrast to the laws of a corrupt society [40: 275]. This romantic aim urged him to 'faithfully present' Tess as 'a pure woman'. Therefore, Hardy can be regarded as an adherent of the temperament doctrine and its biological basis. However, in the debate with his criticasters, Hardy became entangled in his dedication to the purity of Tess's nature and the moral justification of his main character [40].

\section{Representations in Modern Sciences}

\subsection{Genotypical Representations in Biological Research}

In the 20th century, the idea of temperaments as a basic feature of personality regained scientific attention. In the introduction to a handbook of temperament, Rothbart gives an overview of schools of neuro-biological, psychological and psychometric research. For this article, we will pay attention to two scholars, namely Hans Eysenck, representative of the English school of Psychometry, and Jeffrey Gray, a researcher in the tradition of the Eastern to Middle European school, of which Pavlov has become proverbial [2: 6-8].

Eysenck and co-workers has investigated people who were detained in jails and psychiatric clinics. A mathematical method, called factor analysis, was applied in order to extract psychometric dimensions from the data of these investigations. As noted in the discussion of Immanuel Kant's contribution, it is a transition from a pictorial to a mathematical representation.
In 1967, Eysenck issued a major publication on the biological basis of personality. Research results were presented in a two-dimensional design, encompassing an introversion-extraversion dimensions crossing a neuroticism or emotionality dimension [6].

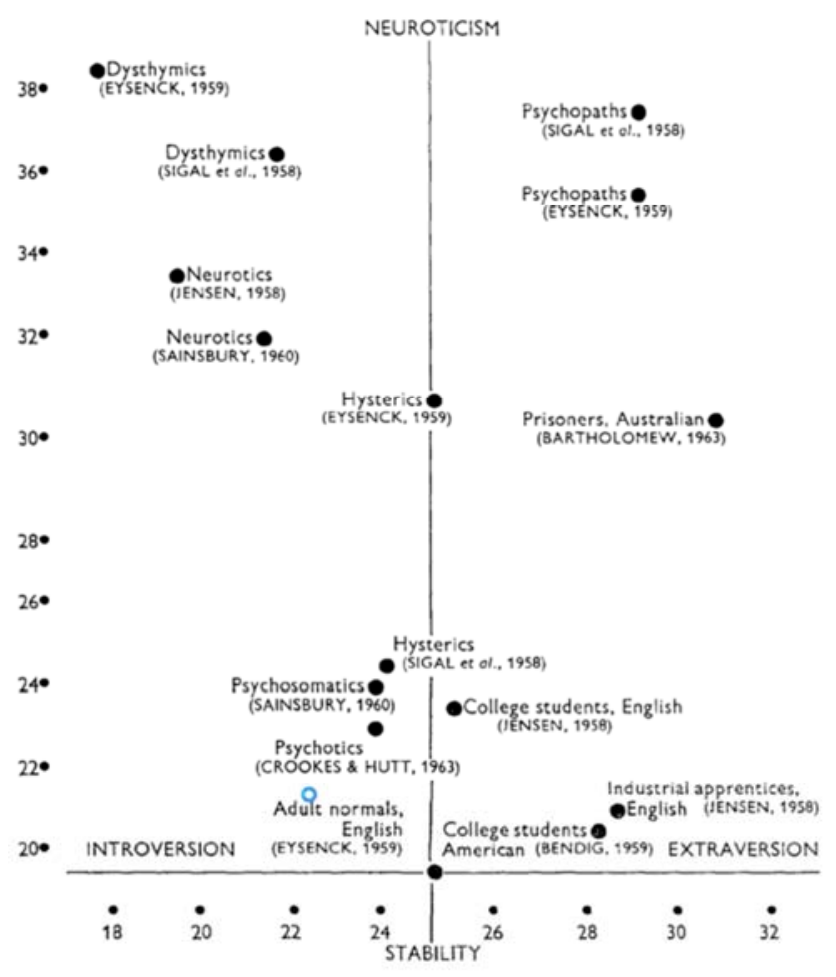

Figure 12. Relationship of dimensions of introversion-extraversion and neuroticism to dysthymic neuroses and psychopathic behavior [7: 250].

Due to the sampling, the data were collected among people who were classified in the range of abnormal psychology. Eysenck claimed that within the range of normal psychology, neurotic extraverts display detrimental behavior as well, like 'various forms of anti-social behavior, juvenile delinquency, sexual delinquency, lying, careless or drunken driving, or more serious breaches of the law' [7:251]. This misbehavior is accompanied by positive affect or pleasure, in contrast to the negative affect and tendency of self-destruction caused by mental illnesses of groups at the left side of the graph.

Gray commented on Eysenck's studies, and came to a rotation of 30 degrees of the factors, resulting in a presentation of the two dimensions of anxiety and impulsivity [7: 254]. Eysenck's dimensions are related to a varying (sensory) sensitivity and thresholds for incoming stimuli (extraversion introversion) and the divergent grades of mobilization of mental resources into response seeking (neuroticism or emotionality), whereas Gray's dimensions display the resulting appearances of behavior. This is the difference between the genotype and the phenotype of biological based personality.

Eysenck's neuroticism dimension was less well-elaborated than his introversion-extraversion dimension [46]. The scale ranges from a neurotic to a normal state of emotional stability (figure 12). In most accounts [47: 287], it is overlooked that a) 
emotionality was both negative and positive oriented, and b) that emotional stability was at the mid of the scale (about 20). Without this truncation, the scale would range from 0 to about 40. Easterbrook relabeled neuroticism into emotionality, and stated that both a high and a low level of emotionality cause problems. At high levels people only funnel at the most salient response cues, and, in most cases neglect consequences of their actions and ignore alternative courses of action. At low levels of emotionality, people fail to process crucial information and do not establish to organize their actions in a proper way [48].

Gray did not propose separate terms for the opposite extremes of his anxiety and impulsivity dimensions. In next figure, we propose apathy [49], respectively comfort.

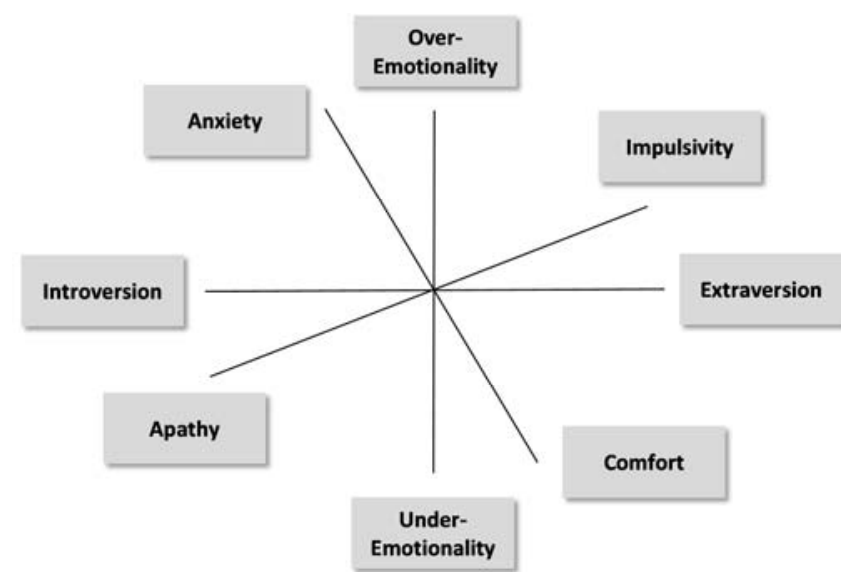

Figure 13. A combination plot of Eysenck's and Gray's dimensions of personality/Revision of Boyce and Ellis [47: 287].

In the literature [50:319, 2: 8], it is persistently overlooked that Gray's rotation was 30 degrees, not 45 degrees [46: 585]. The purport of this difference in rotation is that extraversion is closer to impulsivity than to comfort or sociability [51]. Extraversion in Eysenck's account and impulsivity in Gray's publications consists of a sub factor fun seeking or excitement seeking, an underlying trait that is related to instances of less social or even detrimental behavior.

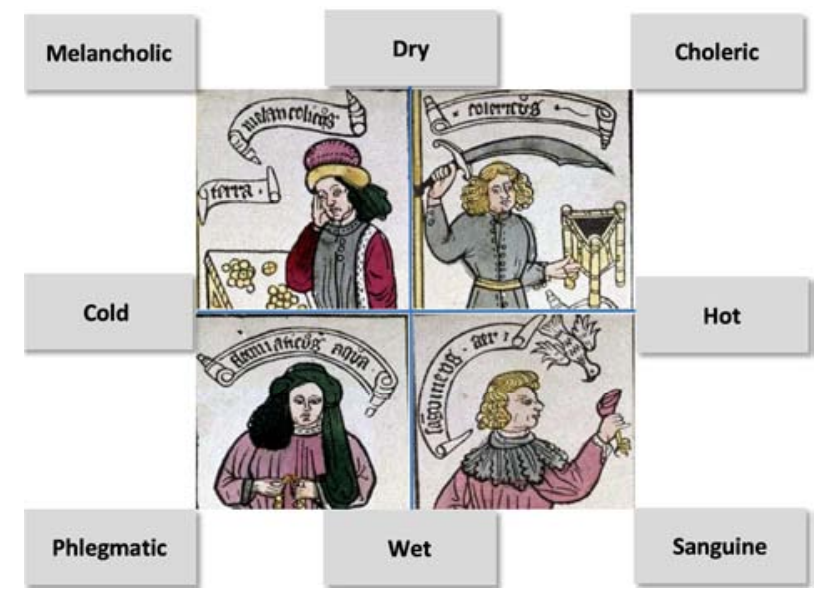

Figure 14. The four temperaments in medieval pictorial representation, ordered along two dimensions.
The similarity between the pictorial medieval model of psychometry and the recent model of biological based personality dimensions is remarkable.

Eysenck's model served as a starting point for the development of a psychometric questionnaires: the Eysenck personality questionnaire (EPQ/PEN), and the NEO-Personality Inventory model of Costa and McCrae, later reworked into the well-known Big Five Factor questionnaires [8]. Both authoritative methods of psychometry have been seriously scrutinized and criticized $[52,53,37,8]$. One of the main points of critique concerned the treatment of impulsivity.

\subsection{A three Dimensional Psychometric Representation}

We start with Eysenck's EPQ-model and later PEN-model. In search of a third personality dimension [54], Eysenck has added psychotism as a dimension. Impulsivity, being a lower level factor of extraversion, was reduced to the positively connotated and leadership related venturesomeness [55, 56], where negative appearances of impulsivity were reattributed to psychotism. By dividing a trait into separate positive and negative dimensions, Eysenck's followed a pattern characteristic for the romance of leadership. By equating neuroticism to negative affect and, implicitly, toward Gray's trait anxiety [56, 57, 58], the spleen of Romanticism was recalled. More importantly for this article, the positive emotionality of impulsivity or neurotic extraversion simply disappeared. The reorganization of the sub factors resulted into a miscellaneous collection of behavioral phenomena: agreeableness (-), coldness, macchiavellianism, hostility, aggression, empathy (-), and consciousness (-) [37]. It is puzzling why Eysenck has associated macchiavellianism, the synonym of political cunning, with psychosis, as this mental illness is characterized by a complete absence of premeditation. All the same, the third factor of Eysenck appeared to be internally inconsistent and inferior to alternatives in explanation of inventory results [37].

\subsection{Five Factor Models for Psychometry (Big Five)}

The addition by Costa and McCrae of openness to experience (E) as a third factor added to Neuroticism and Extraversion in the NEO-model in 1985 was a promising development [8]. It was an attempt to find a third factor for a biologically based model of personality. However, in their revised model [59], Costa and McCrae made a step sideways to layperson's characterizations of personality by Tupes and Cristal [60] and a language-analytical (lexical) approach of Goldberg and colleagues $[61,62,63]$. This latter phenotypical approach aimed at constructing personality by collecting and ordering character-indicating adjectives from the English language. The project resulted in a model of five unlabeled factors. Costa and McCrae intended to amalgamate approaches by redesigning their model and by reordering their data obtained by means of their own, pre-structured questionnaires. They employed a design method based on a shared imagination of personality, leading to the proposition of six facets per factor $[8,64]$, This procedure resulted in a 
'warm' and socialized conception of extraversion. The facets are warmth, gregariousness, activity, excitement seeking, and positive emotions. Both in procedure and in outcome, the revision of the model was romanticist. Extraversion became a one-sided positive attribute of personality, in short a virtue. Particularly, their treatment of the impulsivity sub factor was criticized. It was abstracted from the extraversion factor and rather randomly split into parts of other factors [56]. Costa and McCrae claimed that their extraversion factor was conceptually an equivalent of Goldberg's factor I [59]. A comparison between Costa and McCrae's facets and Goldberg's clusters shows that the next behavioral phenomena are missing:

Table 3. Goldberg clusters not covered by extraversion facets of Costa and McCrae [106], based on Goldberg and Rosolack [37].

\begin{tabular}{ll}
\hline Goldberg cluster & Adjectives included in each cluster \\
\hline Unrestraint & Impetuous, uninhibited, unrestraint \\
Self-esteem & Assured, confident, proud \\
Talkativeness & Talkative, verbose, wordy \\
Animation & Demonstrative, exhibitionistic, flamboyant \\
Ambition & Ambitious, enterprising, opportunistic \\
Unaggressiveness & Unadvantureous, unaggressive, uncompetetive \\
(inverse of) & (inverse of) \\
Shyness (inverse of) & Bashful, shy, timid (inverse of) \\
\hline
\end{tabular}

Apparently, the questionnaires of Costa and McCrae did not cover the dark sides of extraversion. The emphasis on positive aspects of this trait, is an instance of romance of leadership too, as Costa and McCrae equated their extraversion to Tupes and Cristal's first factor surgency [59, 60, 52]. Just like in Eysenck's EPQ/PEN model, neuroticism is redefined into negative emotion. Negative and positive emotionality are no longer conceptually balanced, as neuroticism is a main factor and positive emotion is proposed as a sub-factor of extraversion. In this regard, their model change followed a pattern of Romanticism as well.

Although the Five Factor Model of Costa and McCrae has become a worldwide standard in psychometry, it has been criticized for conceptual, methodological and statistical issues $[52,53,8]$. The critique was discredited by Costa and McCrae, however without a substantial reply to the issues raised by the criticasters $[65,66]$.

An important part of the critique concerns the representation. Aristotle's midway rule for temperaments ('not too much; not too little') is set off. Costa and McCrae utilized a cumulative scale (see example in 15, whereas differential scales (inverse u-curvilinear graphs) were recommendable [64: 7].

According to Block, the Big Five Factor approach dissociates the factors which would otherwise constitute personality in relation [64: 7]. Block's argument is a reminiscence of the ancient idea of the balance (eucrasia) or unbalance (dyscrasia) in the mixture of humors [3:3].

Moreover, at the extreme, the vicious expressions of extraversion become predominant, for instance the tendency to recklessness and a lack of responsibility because of the exclusion of the probability of negative outcomes. In this regard, the highly emotional or neurotic modus of extraversion as a syndrome. People suffering from this syndrome share features with psychopaths, but can be more detrimental to society because of their superior social capabilities $[67,27]$.

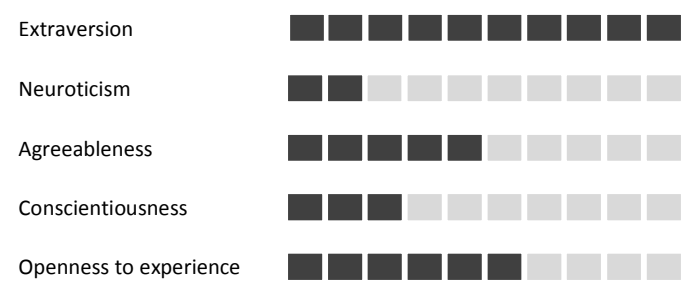

Figure 15. Illustration of cumulative scales.

\subsection{Return to a Two Dimensional Biological Model}

Another representation issue concerns the number of factors: Second instance analyses of the data allow for either two or three super factors on the one hand or a larger number of smaller more specific factors on the other hand [52-54, 65]. Reworked into a larger set of small factors, Hough demonstrates a better prediction of leadership performance and ethical behavior in the modern work place [52]. De Young redesigned the conceptual order of the five factor model of Costa and McCrae, solved some other issues, and the proposed a two-factor model instead, embodying a dimension of stability and a dimension of plasticity (proneness to change) [68]. The two factor model appears to be aligned with findings of recent neuro-physiology [64], according to which the neurotransmitters serotonin and dopamine regulate most basic bodily functions. Dopamine regulates mood and motoric action and plays a vital role in the brain's pleasure and reward systems. The body stores the majority of serotonin in the digestive organs, instead of in the brain. Serotonin helps to regulate mood too, balances body temperature, appetite, and other somatic functions [69]. An appropriate level of serotonin supports physical and mental stability, whereas the dopamine level supports the varying levels of activity.

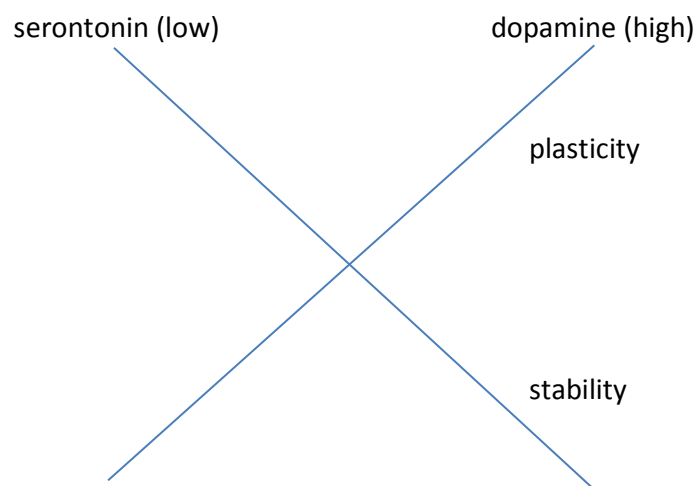

Figure 16. Combination of personality dimensions and regulation by neurotransmitters.

Having too much or too little of either neurotransmitter can cause psychological and physical symptoms. Impulsivity and apathy are the extreme opposites of a dopamine-dependent spectrum of motivated decision making [49]. Sinha, Manohar, 
and Husain relate the extremes with the symptoms of Parkinson's patients (either aggression or apathy), who suffer from a disruption of the dopaminergic homeostasis. These neurotransmitters operate in a interdependent relationship. This joint operation, and the Aristotle's midway rule explain why ambiverts, people in-between introversion and extraversion display significantly better mental health on the long term: 25 years after being grouped along the introversion-extraversion dimension, case-control showed fewer symptoms of cognitive impairment like dementia by ambiverts than by either introverts or extraverts [70].

\section{Conclusion and Discussion}

\subsection{Conclusion}

In the second half of the Middle Ages, representations in primitive wood prints of the four temperaments were made to explicate personal differences. The medieval pinnacle of the four temperaments in arts was the illustration of the Brothers of Limburg, who integrated the temperaments into the body of science of those days. They displayed the four temperaments not by a randomized sequence but by a quadrangular order, forestalling modern psychological representations.

The choleric temperament was illustrated as an outrageous armed man prepared to fight. It is interesting to point out that the choleric temperament was associated with a lack of noble decent and family heritage. This point is illustrated in the way the Frisian hero Grutte Pier was displayed in comparison to Willem van de Marck, Free Lord of Lumey. Both were successful leaders of sea guerilla forces in independence wars in the Netherlands. Both displayed an absence of premeditation, in contrast to more politically cunning fellow combatants.

A major representative of the Ages of Enlightenment, Jean-Jacques Rousseau, has promoted education as the way to bridle impulse and passion. In his treatise he parted with natural man. Immanuel Kant has made a transition from the pictorial to mathematical representation of temperament. Rather close to the most recent scientific representations, he displayed the two dimensions activity and emotionality. $\mathrm{He}$ asserted that although this is the way nature makes man, character is what man makes of himself. Character was seen as the result of interaction of natural temperament on the one hand and regulation and moral reflection on the other hand.

Romanticism has affected the conception of personality as well. Nature is posited outside man, while being in natural scene brings man to his true self. Emotionality is equaled to the melancholic temperament as embodied in the spleen of romantic poets. Modern scholars argue that Romanticism has induced a polarized representation of leadership, either one-sided positive or one-sided negative. Virtues and vices, inherent to human temperament, are made to incongruous features of man.

The heroic tales of János Háry and Tess d'Urbervilles demonstrate a blend of the choleric temperament with the sanguine humor. In case of János Háry, the dedication to action and frankness are exchanged by wordiness and impression making. The musical play demonstrates that extraverted leaders can distort the truth and exploit sentiments of their followers. This article reveal that the symbolic imagery of Thomas Hardy's novel is utilized to contrast the main characters. The reception of his novel has made clear that of the mixed temperaments in Tess, the choleric one has not been acceptable to readers of those days. Another point is the conflict between the satisfaction of Tess in the murder of her rapist and the moral judgments by the audience. In the minds of the audience positive emotionality appears to be incongruous with condemnable impulsive acts.

In the early work of Eysenck and colleagues, a rediscovery of the temperaments has been made, mathematically displaying two dimensions extraversion and neuroticism. When converting this fundamental research into personality tests, two romanticist moves were made: a separation of virtues and vices of impulsivity and a reduction of emotionality to a negative mood state. Costa and McCrae, coiners of the Big Five of Personality, repeat both romanticist moves, Neuroticism is equaled to the negative affect as well. Moreover, they neutralize the impulsivity trait in their extraversion dimension by redistributing aspects randomly over four other dimension. Moreover, they neglect dark-sided aspects of extraverted behavior as found in the balanced account of Goldberg and colleagues. Their lexical approach is based on retrieval and ordering of adjectives attributed to human character.

\subsection{Discussion}

Surprisingly, there is a similarity between the four temperaments in their ancient conception and the most recent advancements in neuro-physiology and brain research. However, the original four bodily fluids were not the very carriers of the temperaments. Instead, the bodily substances of the two neurotransmitters fuel the temperaments. Some of the relationship of temperaments to digestive organs has been found back in recent accounts, however, the causality is reversed and, moreover, far more complex.

Over the years, artists and scholars have struggled with the explication of the impulsive temperament. During the centuries, the leadership temperament rotated from the choleric in the direction of the sanguine temperament. The resulting extraverted character and personality came into the picture, thus raising new problems for explication and interpretation. Leadership requirements have changed from the medieval battlefield to modern society, although some leaders show nostalgia at the expense of opposing people, minority groups, and people in other countries. The development in brain research and neuro-physiology from the middle of the 20th century to the present has followed a continuing line in the research of Gray and colleagues. A sidestep was made for the development of psychometric models of Eysenck and Costa and McCrae. By banning the ambivalence from the traits and by separating virtuous and vicious aspects, the scholars fell prey to romanticism. Since the start of this millennium, a search for the third factor has 
been resumed. Most promising is the idea of self-regulation $[66,71]$, dealing with the alignment between man and his or her environment, and, the adjustment thereby in the expression of the virtues and the vices of their temperaments and by dampening of the outbreaks of affect. However, self-regulation is a limited mental resource [72] that can be upset by impactful events in the life history of people, as the heroes in this article show. It is astonishing how accurate and predictive Immanuel Kant was in his theorizing [2: 6]. Self-regulation has a yet to discover design of innate and educational elements and of conscious and subconscious processes. The question of what constitutes the human character will continue to challenge scholars and to inspire artists.

\section{References}

[1] Boerree, G. C. (2006). Hans Eysenck [1916 - 1997] and other Temperament http://www.ship.edu/\%7Ecgboeree/perscontents.html: Psychology Department/Schippensburg University.

[2] Rothbart, M. K. (2012). Advances in Temperament: History, Concepts, and Measures. In M. Zetner, \& R. L. Shiner, Handbook of Temperament (pp. 3-20). New York: Guilford.

[3] Kalachanis, K., \& Michailidis, I. E. (2015). The Hippocratic View on Humors and Human Temperament. European Journal of Social Behaviour 2 (2): 1-5.

[4] Winter, D. G., John, O. P., Stewart, A. J., Klohnen, E. C., \& Duncan, L. E. (1998). Traits and Motives: Toward an Integration of Two Traditions in Personality Research. Psychological Review, 105 (2): 230-250.

[5] Brittannica, The editors of the Encyclodeadia. (2021). Humour. Retrieved on February 19, 2021, van Ecnyclopaedia: https://www.britannica.com/science/humor-ancient-physiology. Accessed 19 February 2021.

[6] Eysenck, H. J. (1967). The Biological Basis of Personality. Springfiled IL: Charles C. Thomas.

[7] Gray, J. A. (1970). The psychophysiological basis of introversion-extraversion. Behavioral Research \& Therapy, 8: 249-266.

[8] Block, J. (1995). A Contrarian View of the Five-Factor Approach to Personality Description. Psychological Bulletin, 117 (2): 187-215.

[9] Edriss, H., Rosales, B. N., Nugent, C., Conrad, C., \& Nugent, K. (2017). Islamic Medicine in the Middle Ages. The History of Medicine: 223-229.

[10] Commons Wikimedia (2021 April $\left.5^{\text {th }}\right)$. Ret https://commons.wikimedia.org/wiki/File:Figure_representing _one_of_the_four_temperaments._Wellcome_L0003189.jpg.

[11] Verhoeven, C., \& Stufkens, P. J. (2017). Maelwael en de Gebroeders van Limburg, Grondleggers van de Nederlandse schilderkunst [Maelwael and the Brothers of Limburg, Founders of the Dutch painting arts]. Nijmegen: Vantilt.

[12] Raat, M. (2019). Grote Pier (ca. 1480-1520) Een samenvatting van feiten, fictie en beeldvorming omtrent Frieslands bekendste volksheld. [A summary of facts, fiction, and image building on Frisia's most known people's hero]. Historisch Tijdschrift Groniek, 218, 33-47.

[13] De Mik, K. (2021, January 4th). Grutte Pier: Friese volksheld of ordinaire kaper? [Grutte Pier, Fisian people's hero or an ordinary pirate]. Trouw.

[14] Kalma, J. J. (1970). Grote Pier van Kimswerd [Big Pete of Kimswerd. Disseration]. Leeuwarden: De Tille.

[15] Smit, P. (2018, November 19th). Zwarte Piet is wat de Hollanders gemaakt hebben van de Friese held Grutte Pier [Black Pete is what people of Holland have made of the Frisian hero Big Pete]. Trouw.

[16] Zeilmaker, M. (2013). Willem II van der Marck, Vrijheer van Lumey: De vergeten admiraal van de Watergeuzen. [Willem II van der Marck, Free Lord of Lumey: The forgotten admiral of the Water Geuzen. Dissertation]. Leiden: University of Leiden.

[17] Oosterhuis, T. (1996). Lumey de Vossenstaart, Admiraal van de Geuzen [Lumey, the foxtail, admiral of the Geuzen]. Amsterdam.

[18] Lagay, F. (2002, July). The history of humoral medicine. Opgeroepen op February 19, 2021, van History of Medicine.

[19] Veroff, J., \& Veroff, H. B. (1980). Social Incentives: a Life-span developmental approach. New York: Academic Press.

[20] Rousseau, J.-J. (1762). Emile, ou de l'éducation. [Emile or on Education]. Geneve.

[21] Cherpack, C. (1988). Narration and Meaning in Rousseau's Emile. French Forum, 13 (1): 17-30.

[22] Black, J. S. (2021), The Very Pictures of Education: On Rousseau's Illustrations in Emile. Opgeroepen op February 19 2021, van www.adademia.edu: https://www.academia.edu/3875573/The_Very_Pictures_of_E ducation_On_the_Illustrations_in_Rousseaus_Emile.

[23] Collinson, D., Jones, O. S., \& Grint, K. (2018). 'No more Heroes': Critical Perspectives on Leadership romanticism. Organisation Studies, 39 (11): 1629 from 1625-1647.

[24] Meindl, J. R., Ehrlich, S. B., \& Dukerich, J. M. (1985). The Romance of Leadership. Administrative Science Quarterly, 30 (1): 78-102.

[25] Chatterjee, A., \& Hambrick, D. C. (2007). It's all about me: Narcissistic chief executive officers and their effects on company strategy and performance. Administrative Science Quarterly Vol 52 (3): 351-386.

[26] Patterson, C. M., \& Newman, J. P. (1993). Reflectivity and Learning From Aversive Events: Toward a Psychological Mechanism for the Syndromes of Disinhibition. Psychological Review, 100 (4): 716-736.

[27] Ferber, M. (2010). Romanticism: a very short introduction. Oxford University Press: London.

[28] Ferber, M. (2005). A Companion to European romanticism. London: Blackwell Publishing.

[29] Löwy, M., \& Sayre, R. (2001). Romanticism: Against the Tide of Modernism (translated by Catharine Potter). Durham: Duke University Press. 
[30] McKusick, J. C. (2005). Nature. In M. Ferber, A Companion to European Romanticism. London: Blackwell Publishing: 413-432.

[31] Hall, J. (1979). Dictionary of subjects and symbols in art. London: Murray.

[32] Baumgartner, A. (1978). Neuer Koncert Führer: Orchesterwerke, Kammermusiek, Vocalwerke, Von der Gregorianiek bis zur Avantgarde [New Concert Guide: Orchestral Works, Chamber music, Vocal music, From Gregorian chant to Avantgarde]. Vienna: Prisma Verlag: 463.

[33] EMI Records Limited (1975). Carl Nielsen's complete Symphonies. Nielsen's autobiographic notes, cited on record cover.

[34] Ong, C. K. (2011). A Historical Overview and Analysis of the Use of Hungarian Folk Music in Zoltán Kodály's Háry-JánosSuite, Dances of Marosszék, and Dances of Galánta. University of Kansas.

[35] Dalos, A. (2018). Kodály's ideal Kingdom: The Transdormations of singspiel János Háry. Retrieved on March 4, 2021, http://real.mtak.hu/79941/1/11_Dalos_H\%C3\%A1ry_2018.pd f.

[36] Goldberg, L. R., \& Rosolack, T. K. (1994). The Big Five Factor Structure: as an Integrative Framework: An Empirical Comparison with Eysenck's P-E-N Model. In C. F. Halverson Jr., G. A. Kohnstamm, \& R. P. Martin, The Developing Structure of Temperament and Personality from Infancy to Adulthood. New York: Psychology Press: 7-36.

[37] Pierro, A., Cicero, L., Bonaiuto, M., van Knippenberg, D., \& Kruglanski, A. W. (2005). Leader group prototypicality and leadership effectiveness: The moderating role of need for cognitive closure. The Leadership Quarterly, 16: 503-516.

[38] Padilla, A., Hogan, R., \& Kaiser, R. B. (2007). The toxic triangle: Destructive leaders, susceptible followers, and conducive environments. The Leadership Quarterly 18: 176-194.

[39] Parker, L. (1992). "Pure Woman" and Tragic Heroine? Conflicting Myth's in Thomas Hardy's Tess of the d'Urbervilles. Studies in the Novel, 24 (3): 273 from 273-281.

[40] Alvarez, A. (1978). Introduction by A. Alvarez. In T. Hardy, Tess of the d'Urbervilles. London: Penguin: 11-23

[41] Lovesey, O. (2003). Deconstructing Tess. Studies in English Literature, 1500-1900, Autumn, 2003, 43 (4): 913-938.

[42] Hardy, T. (1978). Tess of the d'Urbervilles: A Pure Woman ((version Edited by D. Skilton). London: Pengui.

[43] Van Ghent, D. (1953). The English Novel: Form and Function. Reinhart \& Winston: Holt.

[44] Kowalchuk, K. (1985). Symbolic Imagery in Four Novel by Thomas Hardy. McMatser: 91-93.

[45] Matthews, G., \& Gilliland, K. (1999). The personality theories of H. J. Eysenck and J. A. Gray:: A Comparative Review. Personality and Individual Difference, 26: 617 from 583-626.

[46] Boyce, W. T., \& Ellis, B. J. (2005). Biological sensitivity to context: An evolutionary-developmental theory of the origins and functions of stress reactivity. Development and Psychopathology, 17, 287 from: 271-301.
[47] Easterbrook, J. A. (1959). The effect of emotion on cue utilization and the organization of. Psychological Review, 66 (3): 183-201.

[48] Sinha, N., Manohar, S., \& Husain, M. (2013). Impulsivity and apathy in Parkinson's disease. Journal of Neuropsychology, 7: 255-283.

[49] Carver, C. S., \& White, T. L. (1994). Behavioral inhibition, behavioral activation, and affective responses to impending reward and punishment. Journal of Personality and Social Psychology, 67: 319 from 319.333.

[50] Humphreys, M. S., \& Revelle, W. (1984). Personality, Motivation, and Performance: A Theory of the Relationship Between Individual Differences and Information Processing. Psychological Review, 91 (2): 170 from 153-183.

[51] Hough, L. M. (1992). The 'Big Five'Personality Variables Construct Confusion. Description versus Prediction. Human Performance, 5 (1_2), 139-155.

[52] Eysenck, H. J. (1992). Four ways five factors are not basic. Personality and Individual Differences, 6: 667-673.

[53] Eysenck, H. J. (1994). The Big Five or the Giant Three: Criteria for a Paradigm. In C. F. Halverson, G. A. Kohnstamm, \& R. P. Martin, The Developing Structure of Temperament and Personality from Infancy to Adulthood. New York: Psychology Press: 37-52.

[54] Eysenck, H. J., \& Eysenck, M. W. (1985). Personality and Individual Differences: A Natural Science Approach. New York: Plenmu Press.

[55] Whiteside, S. P., \& Lynam, D. R. (2001). The Five Factor Model and impulsivity: using a structural model of personality to understand impulsivity. Journal of Personality and Individual Differences: 669-689.

[56] Gray, J. A. (1981). A critique of Eysenck's theory of personality. In H. J. Eysenck, A Model for Personality (pp. 146-176). Berlin: Springer Verlag: 146-176.

[57] El-Zahhar, N., \& Hocevar, D. (1984). Anxiety, Arousability and Neuroticism. https://files.eric.ed.gov/fulltext/ED247516.pdf: EDRS.

[58] Costa, P. T., \& McCrae, R. R. (1992). Four ways five factors are basic. Personality and Individual Differences, 13 (6): 653-665.

[59] Tupes, E. C., \& Christal, R. E. (1961). Recurrent Personality Factors Based on Trait Ratings. Arlington, VA: Armed Services Technical Information Agency.

[60] Goldberg, L. R. (1981). Language and individual differences: The search for universals in personality lexicons. In L. Wheeler, Review of personality and social psychology. 2 (pp. 141-165'). Beverly Hills: Sage.

[61] Goldberg, L. R. (1992). The Development of Markers for the Big-Five Factor Structure. Psychological Assessment, 4 (1): 26-42.

[62] Goldberg, L. R. (1993). The Structure of Phenotypic Personality Traits. American Psychologist, 48 (1): 26-34.

[63] Block, J. (2010). The Five-Factor Framing of Personality and Beyond: Some Ruminations. Psychological Inquiiy, 21: $2-25$. 
[64] Costa, P. T., \& McCrae, R. R. (1995). Solid ground in the wetlands of personality: A reply to Block. Psychological Bulletin, 117 (2): 216-220.

[65] Block, J. (1995b). Going Beyond the Five Factors Given: Rejoinder to Costa and McCrae (1995) and Goldberg and Saucier (1995). Psychological Bulletin, 117 (2): 226-229.

[66] Zinbarg, R., \& Revelle, W. (1989). Personality and Conditioning: A Test of Four Models. Journal of Personality and Social Psychology, 57 (2): 301-314.

[67] De Young, C. G. (2006). Higher-Order Factors of the Big Five in a Multi-Informant Sample. Journal of Personality and Social Psychology, 91 (6): 1138-1151.

[68] For a popularized account see: Eske, J., \& Moawad, H. (2019,
August 19). Dopamine and serotonin: Brain chemicals explained. Retrieved on March 15, 2019, https://www.medicalnewstoday.com/articles/326090.

[69] Crowe, M., Andel, R., Pedersen, N. L., Fratgilioni, L., \& Gatz, M. (2006). Personality and Risk of Cognitive Impairment 25 Years Later. Psychology and Aging, 25) 3', 573-580.

[70] Kuhl, J. (2018). Individual Differences in Self-Regulation. In J. Heckhausen, \& H. Heckhausen, Motivation and Actions (third edition). New York: Springer: 529-573.

[71] Welsh, D. T., \& Ordóñez, L. D. (2014). The dark side of consecutive high performance goals: Linking goal. Organizational Behavior and Human Decision Processes, 123: 79-89. 